\title{
非自己遮蔽型サイクロトロン設置施設における 法改正に基づく放射化物の除染の試み
}

\author{
小宮 $\quad$ 勲 $^{1} \quad$ 梅津芳幸 ${ }^{1}$ 藤淵俊王 $^{2}$ 中村和正 $^{3}$ 馬場眞吾 $^{4}$ 本田 浩 $^{4}$ \\ 1 九州大学病院医療技術部放射線部門 \\ 2 九州大学大学院医学研究院保健学部門医用量子線科学分野 \\ 3 浜松医科大学放射線腫瘍学講座 \\ ${ }^{4}$ 九州大学大学院医学研究院臨床放射線科学分野
}

論文受付

2015 年 11 月 17 日

論文受理

2016 年 7 月 27 日

Code No. 633

緒 言

医療機関における小型サイクロトロンは，ポジトロ ン放出核種製造のため, わが国で約 150 台が稼働 ${ }^{1)} し$ ている，当施設のサイクロトロンは, 1983 年に設置し た非自己遮蔽型 $(\mathrm{BC} 1710$ ：日本製鋼社製)で，装置老朽 化のため 2009 年 6 月に運転を停止した。
停止後, 約 5 年が経過した 2014 年にサイクロトロ ン本体を含むサイクロトロン設置施設を廃棄するため の諸手続きを経験した。廃棄にあたり，法令に基づい た放射化物の選別，放射化による污染状況の確認方 法, 污染範囲の評価, 除染範囲の決定, 除染後の確認 方法についてまとめる。

\section{Decontamination of the Activation Product Based on a Legal Revision of the Cyclotron Vault Room on the Non-self-shield Compact Medical Cyclotron}

\author{
Isao Komiya, ${ }^{1 *}$ Yoshiyuki Umezu, ${ }^{1}$ Toshioh Fujibuchi, ${ }^{2}$ Kazumasa Nakamura, ${ }^{3}$ Shingo Baba, ${ }^{4}$ \\ and Hiroshi Honda ${ }^{4}$ \\ ${ }^{1}$ Division of Radiology, Department of Medical Technology, Kyushu University Hospital \\ ${ }^{2}$ Division of Medical Quantum Science, Department of Health Sciences, Faculty of Medical Sciences, Graduate School of \\ Medical Sciences, Kyushu University \\ ${ }^{3}$ Department of Radiation Oncology, Hamamatsu University School of Medicine \\ ${ }^{4}$ Department of Clinical Radiology, Graduate School of Medical Sciences, Kyushu University
}

Received November 17, 2015; Revision accepted July 27, 2016

Code No. 633

\section{Summary}

The non-self-shield compact medical cyclotron and the cyclotron vault room were in operation for 27 years. They have now been decommissioned. We efficiently implemented a technique to identify an activation product in the cyclotron vault room. Firstly, the distribution of radioactive concentrations in the concrete of the cyclotron vault room was estimated by calculation from the record of the cyclotron operation. Secondly, the comparison of calculated results with an actual measurement was performed using a NaI scintillation survey meter and a highpurity germanium detector. The calculated values were overestimated as compared to the values measured using the $\mathrm{NaI}$ scintillation survey meter and the high-purity germanium detector. However, it could limit the decontamination area. By simulating the activation range, we were able to minimize the concrete core sampling. Finally, the appropriate range of radioactivated area in the cyclotron vault room was decontaminated based on the results of the calculation. After decontamination, the radioactive concentration was below the detection limit value in all areas inside the cyclotron vault room. By these procedures, the decommissioning process of the cyclotron vault room was more efficiently performed.

Key words: compact medical cyclotron, non-self-shield, radioactive waste, decontamination, radioactive concentration

*Proceeding author 
Table 1 The PET isotopes' nuclear reactions and the record of operations ${ }^{4)}$

\begin{tabular}{lccc}
\hline \hline $\begin{array}{r}\text { Nuclear } \\
\text { reaction }\end{array}$ & $\begin{array}{c}\text { Number of } \\
\text { Operations per year } \\
(\mathrm{n} / \text { year })\end{array}$ & $\begin{array}{c}\text { Beam time per year } \\
(\mathrm{h} / \text { year })\end{array}$ & $\begin{array}{c}\text { Average beam } \\
\text { current }(\mu \mathrm{A})\end{array}$ \\
\hline${ }^{14} \mathrm{~N}(\mathrm{p}, \alpha)^{11} \mathrm{C}$ & 23.6 & 12.0 & 34.1 \\
$\left.{ }^{16} \mathrm{O}(\mathrm{p}, \alpha)\right)^{13} \mathrm{~N}$ & 0.9 & 0.2 & 3.7 \\
${ }^{14} \mathrm{~N}(\mathrm{~d}, \mathrm{n}){ }^{15} \mathrm{O}$ & 125.8 & 88.5 & 12.3 \\
${ }^{18} \mathrm{O}(\mathrm{p}, \mathrm{n}){ }^{18} \mathrm{~F}$ & 29.3 & 46.6 & 36.4 \\
${ }^{20} \mathrm{Ne}(\mathrm{d}, \alpha)^{18} \mathrm{~F}$ & 57.8 & 60.5 & 25.7 \\
Total & 237.4 & 207.8 & 20.7 \\
\hline
\end{tabular}

\section{1. 方 法}

サイクロトロン本体扔よび周辺機器は, 放射化して いる可能性が高く，放射性同位元素等による放射線障 害の防止に関する法律(障害防止法)の改正 ${ }^{2)}$ に基づ き, 放射性廃妄物は許可廃棄業者である公益社団法人 日本アイソトープ協会に引き渡す（放射性廃棄物とし て廃棄)こととした

サイクロトロン室の床, 壁, 天井面のコンクリート に㧍ける放射化による污染の評価および除染の手順を 次のと打りとした。

(1) 計算による放射能濃度分布を求め, 放射化による 污染範囲の決定

(2) 床, 壁, 天井面の污染範囲評価のため, 校正された $\mathrm{NaI}$ シンチレーションサーベイメータ（TCS172B：日立アロカメディカル株式会社製)による各 面の計数率の測定

(3) 深さ方向の污染範囲評価のため, コンクリートを コア抜きしたサンプルを高純度ゲルマニウム (high purity : HP-Ge) 半導体検出器 (GMX25P4: セイ コー・イージーアンドジー株式会社製)で放射能濃 度を測定

(4) (2)と(3)の結果より (1)の計算結果の妥当性を確認し, 安全側に除染範囲を決定

(5) 決定した除染範囲を除去し放射性廃棄物として廃棄

(6) 除染されたコンクリート面を含め全面をサーベイ メータで測定

上記の作業により，污染除去を確認した．

ここで, 污染範囲の決定における判断基準は, 障害

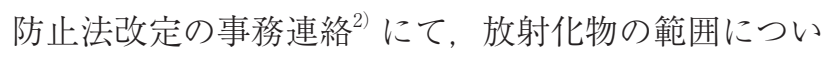
て「放射化物として取り扱うか否かの判断は, 放射性 污染物の確認制度の導入に伴って告示として規定した 放射能濃度及びその設定の考元方が参考となる」とあ り，これらも参考にして污染範囲を除去すれば，残っ たコンクリートに污染がないということ，つまり当施 設ではサーベイメータで検出限界以下となることを採 用した。
以下, 詳細について示す.

\section{1-1 計算による放射能濃度の算出と污染範囲の決定}

運転履歷をもとに中性子発生量を推定し, サイクロ トロン室の床, 壁, 天井面のコンクリートの放射能濃 度を算出し, 污染範囲を決定した。

ここで, 運転履歴として, サイクロトロンの運転期 間は, 1983 年 3 月から 2009 年 6 月の 27 年 3 カ月で あった。加速エネルギーは, 陽子 $17 \mathrm{MeV}$, 重陽子 10 $\mathrm{MeV}$ である。使用した加速粒子と核反応，1年あたり の運転回数, 運転時間, 平均ビーム電流など運転状況 の詳細

\section{1-1-1 中性子発生量の推定}

放射化によるコンクリートの放射能濃度を計算する には，サイクロトロンの中性子発生量が必要となる。 非自己遮蔽型サイクロトロンの熱中性子フルエンス率 は運転中に扔いて, ターゲットボックス内で $10^{7}$ $\mathrm{cm}^{-2} \mathrm{~s}^{-1}$, ターゲットボックス外の近傍で $10^{6} \mathrm{~cm}^{-2} \mathrm{~s}^{-1}$, サイクロトロン周辺部の通常運転状況下で $10^{5} \mathrm{~cm}^{-2} \mathrm{~s}^{-1}$ 程度と予想される ${ }^{5-8)}$. 当該サイクロトロンは運転停 止し，運転時の熱中性子フルエンス率を測定できない ため, 後述の放射能濃度の計算式を検証するために, 当施設で事前にコンクリートをコア抜きして測定した 放射能濃度 ${ }^{4)}$ と計算值を比較し, 熱中性子フルエンス 率を推定し決定した。

\section{1-1-2 コンクリート中の放射能濃度の推定}

コンクリート中の放射能濃度の評価にあたり, 下記 の手順で計算した。

生成対象核種として, ${ }^{60} \mathrm{Co},{ }^{152} \mathrm{Eu},{ }^{134} \mathrm{Cs},{ }^{46} \mathrm{Sc},{ }^{3} \mathrm{H}$ が 挙げられるが, 運転停止後 5 年経過している場合, 後 述の放射能濃度の計算式にて, これらのうち ${ }^{134} \mathrm{Cs}$, ${ }^{46} \mathrm{Sc},{ }^{3} \mathrm{H}$ は, 放射化の寄与は合計しても5\%未満と なったため, ${ }^{60} \mathrm{Co},{ }^{152} \mathrm{Eu} の 2$ 核種を対象泉 10) とした. これらの放射化が起こる核反応は ${ }^{59} \mathrm{Co}(\mathrm{n}, \gamma){ }^{60} \mathrm{Co}$, ${ }^{151} \mathrm{Eu}(\mathrm{n}, \curlyvee){ }^{152} \mathrm{Eu}$ である.

下記の式(1)により，コンクリート中の放射能濃度 
を計算した。

$\mathrm{A}=\mathrm{N} \times \mathrm{f} \times \sigma \times \mathrm{S}$

ここで, $\mathrm{A}$ : 放射能濃度 $(\mathrm{Bq} / \mathrm{g}), \mathrm{N}$ : 原子数 $\left(\mathrm{g}^{-1}\right), \mathrm{f}$ : 熱中性子フルエンス率 $\left(\mathrm{cm}^{-2} \mathrm{~s}^{-1}\right), \sigma$ : 熱中性子捕獲反応 断面積 $\left(\mathrm{cm}^{2}\right), \mathrm{S}$ : 飽和係数である.

飽和係数 S は, 長期間運転する場合, 最初にできた 放射能も減衰していくための補正であり, 下記の式 (2)より計算した.

$\mathrm{S}=1-\exp (-\lambda \times t)$

ここで， $\lambda$ : 壊変定数 $\left(\mathrm{s}^{-1}\right), \mathrm{t}$ : 運転期間 $(\mathrm{s})$ である.

コンクリート中の Co, Euの濃度は, 一般的に公開 されているデータ ${ }^{9)}$ を参考にし，それぞれ $12 \mathrm{ppm,}$

$0.73 \mathrm{ppm}$ とした.

${ }^{59} \mathrm{Co}(\mathrm{n}, \gamma){ }^{60} \mathrm{Co},{ }^{151} \mathrm{Eu}(\mathrm{n}, \gamma){ }^{152} \mathrm{Eu}$ の熱中性子捕獲反応 断面積 ${ }^{10)}$ は，それぞれ 37.18 barn, 5900 barn とした。

1-1-1で得られた熱中性子フルエンス率は運転時の 值であり，過去の使用記録によるとサイクロトロンは 1 年間あたり平均 207.8 時間運転していたことから, $1.3 \times 10^{6} \times(207.8 / 365 / 24)=3.08 \times 10^{4} \mathrm{~cm}^{-2} \mathrm{~s}^{-1}$ の熱中性子フ ルエンス率で常に熱中性子を発生しているものとして 計算した

中性子の発生源として, サイクロトロン本体の放射 化をサーベイメータで評価したところ, ターゲットの ほか, ターゲットへのビームポート, 磁気チャンネル, デフレクタで放射化がみられたことから，これらを考 慮した。ヨーク自体が中性子の遮蔽体となることも考 慮し, ターゲットからの中性子発生量に対する各部位 の中性子発生割合をターゲットへのビームポートで $5 \%$, 磁気チャンネルで 8\%, デフレクタで $25 \%$ とそれ ぞれ推定した。 これらは本体内部の計数率をサーベイ メータで測定し，その結果より推定したものである。 またターゲットからの中性子の指向性やターゲット付 近の周辺機器との散乱を考慮し, 中性子源をビーム進 行方向に $100 \mathrm{~cm}$ 拡張した.

サイクロトロン室の床, 壁, 天井面のコンクリート 表面での熱中性子フルエンス分布は，これらの中性子 発生源から距離の逆二乗則に従って減弱し, サイクロ トロン室内に広がるものとして計算した。

また，ビーム進行方向の壁の手前には厚さ $20 \mathrm{~cm} の$ 中性子遮蔽壁(ポリエチレン)が配置されていた。その ため，遮蔽体のあった部分の裏側は熱中性子フルエン ス率が表側の $1 / 10$ に減弱するものと推定して計算した。

これまでの文献 ${ }^{11 \sim 13)}$ や報告より，表面から $10 \mathrm{~cm}$ 程度までは濃度はほとんど変わらず，以深では放射能
濃度は指数関数的に低下する。ここで, 深さ方向の減 衰割合は，これらの文献や測定值を参考にし，表面か ら $10 \mathrm{~cm}$ のピークを 1 とすると, $20 \mathrm{~cm}$ で $0.7,30 \mathrm{~cm}$ で 0.3 として計算した.

これらの放射能濃度の算出においては，サイクロト ロン本体, その他の周辺機器による遮蔽効果は考慮し ていない.

\section{1-2 サーベイメータ, HP-Ge 半導体検出器による計} 算結果の検証

1-2-1 Nal シンチレーションサーベイメータを用い た間接法による計数率の測定

コンクリートの床，壁，天井面の放射化による污染 状況を評価するため, サイクロトロン室の床面を 30 $\mathrm{cm}$ 間隔，壁面と天井面を $50 \mathrm{~cm}$ あるいは $70 \mathrm{~cm}$ 間隔 で区画し，任意の測定点を設定した。また，サーベイ メータの検出器を測定点に密着させ測定した。測定点 以外の周囲からの放射線の影響を受けにくくするため に, 区画周囲に高さ $10 \mathrm{~cm}$, 厚さ $5 \mathrm{~cm}$ の鉛ブロック を配置し測定した。

測定結果を下記の式 $(3)$ より算出した検出限界值 $(3 \sigma$ 法)と比較した。

$\mathrm{N}_{\mathrm{d}}=\frac{\mathrm{K}}{2} \times\left\{\frac{\mathrm{K}}{\mathrm{t}}+\sqrt{\left(\frac{\mathrm{K}}{\mathrm{t}}\right)^{2}+4 \times \mathrm{N}_{\mathrm{b}} \times\left(\frac{1}{\mathrm{t}}+\frac{1}{\mathrm{t}_{\mathrm{b}}}\right)}\right\}$

$\mathrm{N}_{\mathrm{d}}$ : 検出限界計数率 $(\mathrm{cps})$

$\mathrm{N}_{\mathrm{b}}$ : バックグランドの計数率 $(\mathrm{cps})$

$\mathrm{K}$ ：信頼の水準によって決定される定数 $(\mathrm{K}=3$ とする $)$

$\mathrm{t}$ : 試料の測定時間 $(\mathrm{s})$

$t_{b} \quad$ : バックグランドの測定時間 $(\mathrm{s})$

時定数 $\tau(\mathrm{s})$ を用いる場合は $\mathrm{t}=2 \tau, \mathrm{t}_{\mathrm{b}}=2 \tau$ とする

\section{1-2-2 HP-Ge 半導体検出器を用いた直接法による放 射能濃度の測定}

コンクリートの深さ方向の放射化による污染状況を 評価するため，計算による放射能濃度分布の結果を参 考に測定箇所を決めた。コンクリートコアは深さ 45 $\mathrm{cm} \times$ 直径 $4 \mathrm{~cm} \phi$ を取り, 深さ $10 \mathrm{~cm}(7 \sim 13 \mathrm{~cm})$, 深さ $20 \mathrm{~cm}(17 \sim 23 \mathrm{~cm})$, 深さ $30 \mathrm{~cm}(27 \sim 33 \mathrm{~cm})$, 深さ 40 $\mathrm{cm}(37 \sim 43 \mathrm{~cm})$ のコンクリートサンプル (U-8 容器)を 作成し, HP-Ge 半導体検出器でそれぞれ 3600 秒間測 定した。

\section{1-3 除染範囲の決定}

計算より求めた污染範囲が安全側に評価されている ことの確認は, サーベイメータおよび HP-Ge 半導体 検出器の測定結果が計算結果より過大評価されている 

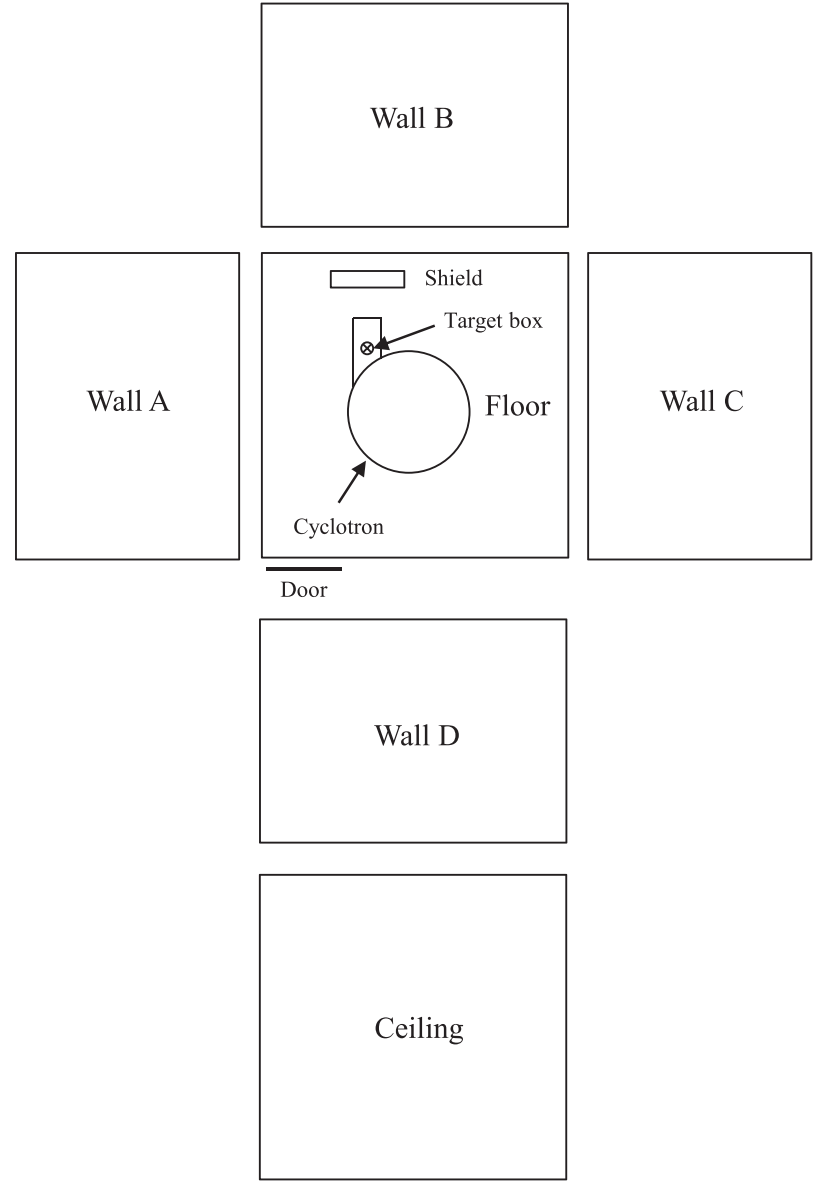

Fig. 1 The development diagram of the cyclotron vault room.

かどうかで判断し，その上で，床，壁，天井面方向と 深さ方向で除染範囲を決定した。

\section{1-4 放射化物の除去後の確認}

放射化物を除去した後, サイクロトロン室の床, 壁, 天井面を，1-2-1 と同様の区画にて，サーベイメー夕を 使用し, 検出器を測定点に密着させ測定した。 バック グラウンドを下げるために, 検出器専用の厚さ $1 \mathrm{~cm}$ の鉛シールド(プローブ用遮蔽体，OTA-110505：株式 会社千代田テクノル製)を使用し測定した。

測定結果を 1-2-1 と同様に算出した検出限界值と比 較した

\section{2. 結 果}

\section{2-1 計算による放射能濃度の算出と污染範囲の決定}

\section{2-1-1 中性子発生量の推定}

サイクロトロン室のコンクリートの放射化評価に掠 いて，ターゲットボックス外(ターゲットから床方向 に向って $120 \mathrm{~cm}$ の位置)での熱中性子フルエンス率 を $1.3 \times 10^{6} \mathrm{~cm}^{-2} \mathrm{~s}^{-1}$ と推定した。 今回の結果は文献 值 ${ }^{5-8)}$ とほぼ同等の值であり，推定が妥当とあると判
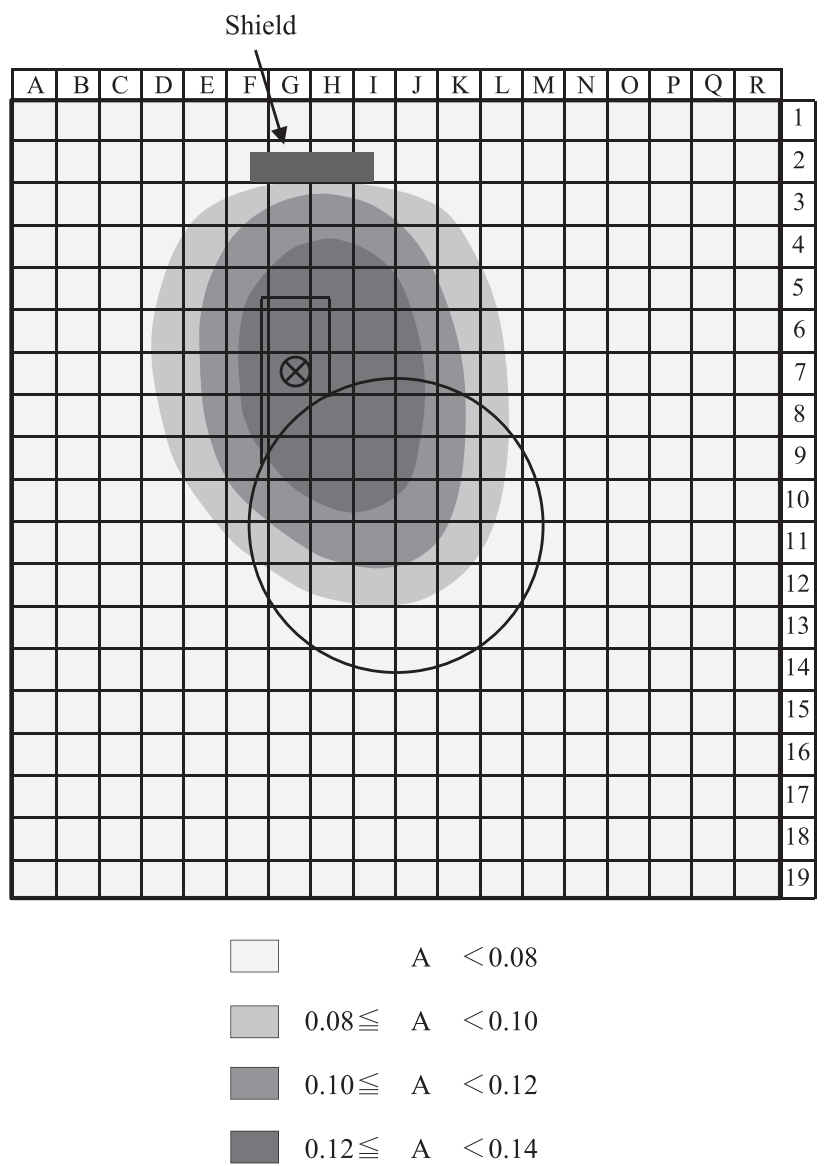

A : The sum of radioactive concentrations ${ }^{60} \mathrm{Co}$ and ${ }^{152} \mathrm{Eu}(\mathrm{Bq} / \mathrm{g})$

Fig. 2 The calculated radioactive concentration map of the floor (depth: $0-10 \mathrm{~cm}$ ).

断した。

\section{2-1-2 コンクリート中の放射能濃度の計算結果}

放射能濃度分布については, 床, 壁 $\mathrm{A}$ から壁 $\mathrm{D}$, 天 井を Fig. 1 のように設定し, $30 \mathrm{~cm}$ 間隔の評価点で放 射能濃度を算出し分布図を作成した。放射能濃度は 2014 年 10 月時点における計算值である. Fig. 2 に床 面, Fig. 3 に壁 A 面に扔ける深さ 0 10 cm の放射能 濃度分布図を示す。なお，壁 B～D 面，天井面におい ては壁 $\mathrm{A}$ 面と同様の放射能濃度分布を呈した。

床面に扔いては，深さ方向の評価として，深さ 20 $\mathrm{cm}$ (Fig. 4), 深さ $30 \mathrm{~cm}$ (Fig. 5)の位置での放射能濃 度分布図を示す。

計算結果では，床面の一部が放射化されており，壁， 天井面は放射化されていないと判断した。

計算による放射能濃度分布より，污染範囲は，床面 において本体ターゲット直下をほぼ中心に縦 $3.0 \mathrm{~m} \times$ 横 $2.7 \mathrm{~m}$ とした。また，深さ方向については $30 \mathrm{~cm}$ ま でを污染範囲とした。 


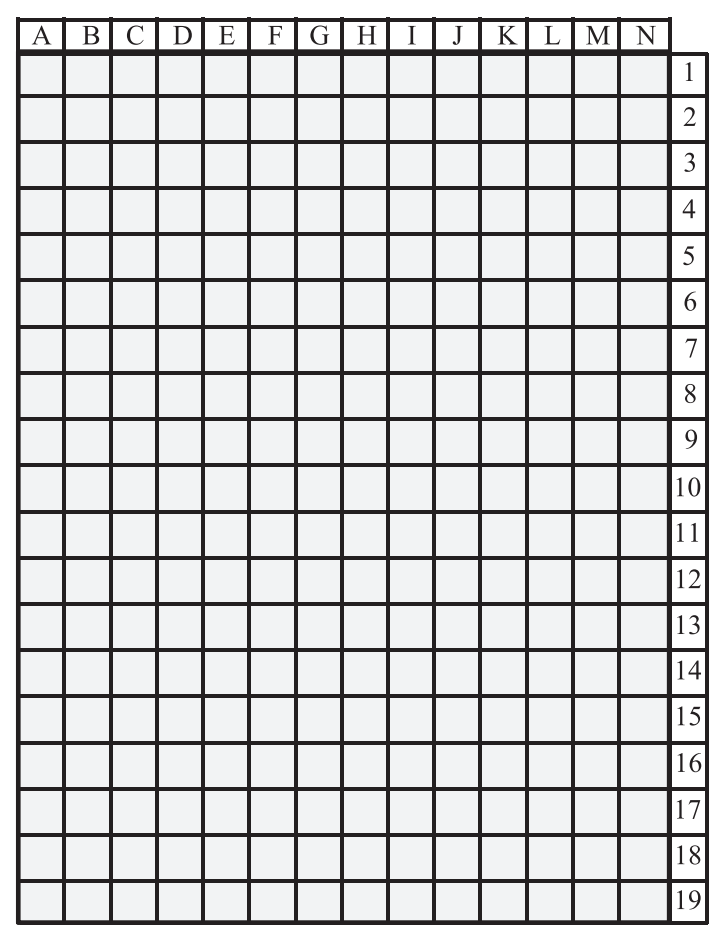

A $<0.08$

A : The sum of radioactive concentrations ${ }^{60} \mathrm{Co}$ and ${ }^{152} \mathrm{Eu}(\mathrm{Bq} / \mathrm{g})$

Fig. 3 The calculated radioactive concentration map of the wall A (depth: 0-10 cm).

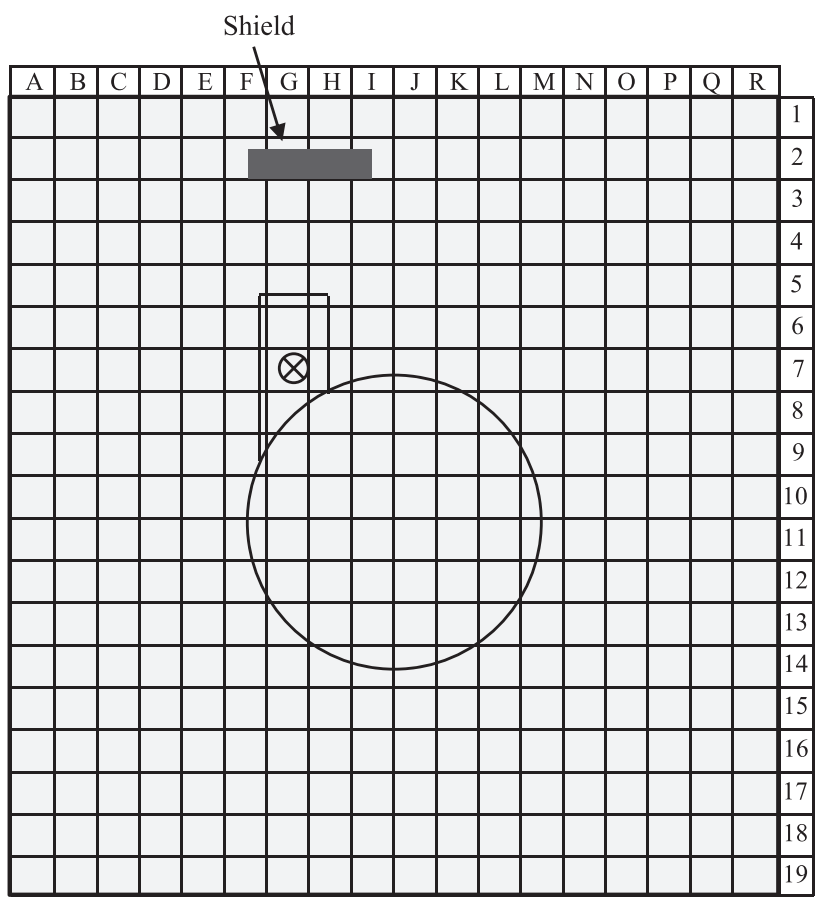

A $<0.08$

A : The sum of radioactive concentrations ${ }^{60} \mathrm{Co}$ and ${ }^{152} \mathrm{Eu}(\mathrm{Bq} / \mathrm{g})$

Fig. 5 The calculated radioactive concentration map of the floor (depth: $30 \mathrm{~cm}$ ).
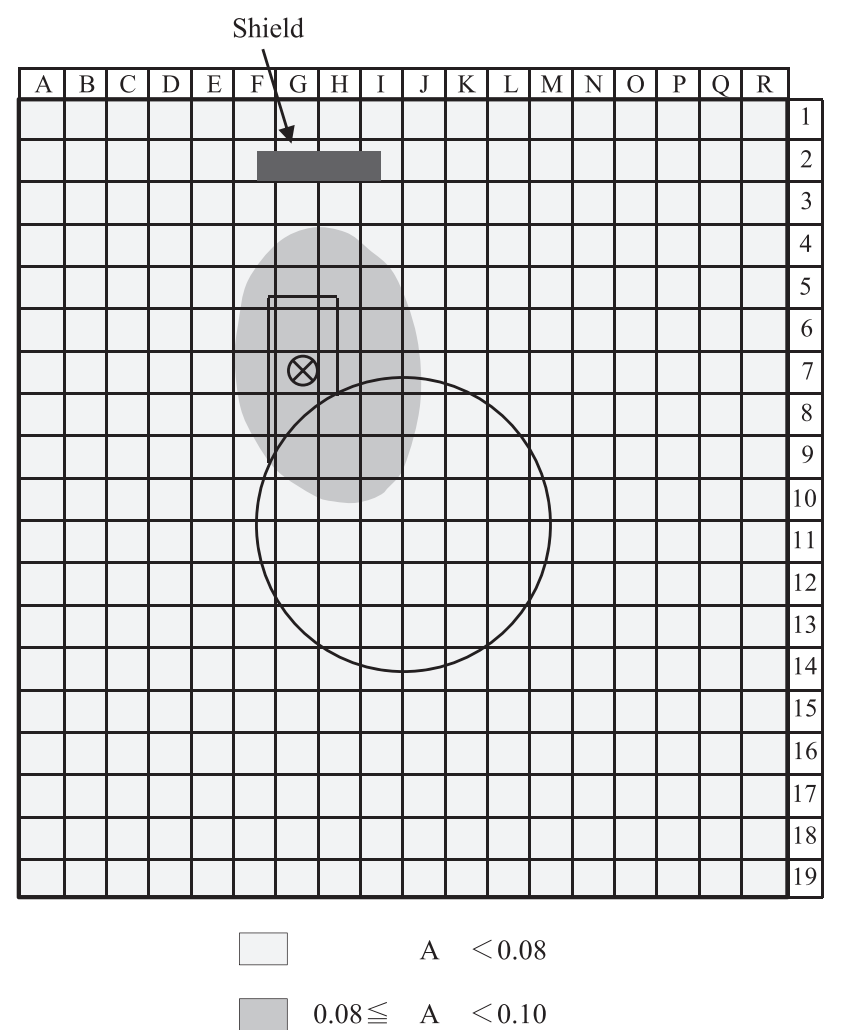

$\mathrm{A}:$ The sum of radioactive concentrations ${ }^{60} \mathrm{Co}$ and ${ }^{152} \mathrm{Eu}(\mathrm{Bq} / \mathrm{g})$

Fig. 4 The calculated radioactive concentration map of the floor (depth: $20 \mathrm{~cm}$ ).

2-2 サーベイメータ, HP-Ge 半導体検出器による計 算結果の検証

2-2-1 Nal シンチレーションサーベイメータによる 計数率の測定結果

サーベイメータによる測定結果を, 床面を Fig. 6 , 壁，天井面を Fig. 7 に示す。床面に関してはターゲッ 卜付近が高值を示し周囲に行くにつれて值が低くなる 傾向があった。また，壁，天井面ではわずかに検出限 界值を超える点が複数みられた。

2-2-2 HP-Ge 半導体検出器による放射能濃度の測定 結果

コンクリートのコア抜き箇所は計算による放射化濃 度分布の結果を参考に 15 力所 Fig. 8) とした。ここ で，区画番号 E-11 と J-11については，十分な深さの コア抜きができず，深さ $10 \mathrm{~cm}$ のデータのみである. 各測定ポイントの核種ごとの放射能濃度とその合計を Table 2 に示す. ターゲット付近は高值を示し, ター ゲットから離れるにつれて值が低くなる傾向があっ た。また，すべてのポイントで長半減期核種である ${ }^{60} \mathrm{Co}$ と ${ }^{152} \mathrm{Eu}$ のみが検出され, ${ }^{134} \mathrm{Cs},{ }^{46} \mathrm{Sc},{ }^{3} \mathrm{H}$ 等は検出 されなかった。 


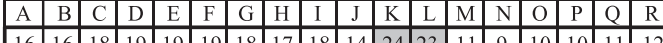

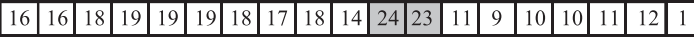
\begin{tabular}{|l|llllllllllllllllllllll}
13 & 11 & 20 & 22 & 22 & 25 & 25 & 25 & 25 & 24 & 25 & 23 & 10 & 10 & 9 & 10 & 10 & 14 & 2 \\
\hline
\end{tabular} \begin{tabular}{|l|lllllllllllllllllllllll}
13 & 18 & 24 & 22 & 23 & 27 & 27 & 28 & 26 & 23 & 25 & 23 & 10 & 8 & 10 & 10 & 10 & 19 & 3 \\
\hline 14 & 1 & 22 & 2 & 25 & 28 & 30 & 29 & 30 & 28 & 25 & 25 & 10 & & 0 &
\end{tabular}

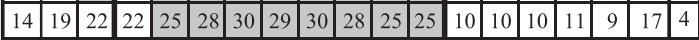

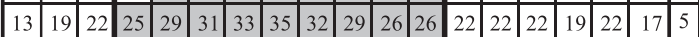
\begin{tabular}{lllllllllllllllllllllllll}
\hline 13 & 14 & 23 & 22 & 26 & 33 & 36 & 37 & 32 & 30 & 26 & 23 & 21 & 23 & 23 & 22 & 19 & 17 & 6 \\
\hline 13 & 1 & 20 & 20 & 27 & 32 & 40 & & & 3 & 30 & 28 & 23 & 24 & 23 & 23 & 22 & 20 & 18 & 7 \\
\hline
\end{tabular} \begin{tabular}{lllllllllllllllllllllll|l}
13 & 11 & 20 & 20 & 27 & 32 & 40 & 40 & 35 & 30 & 28 & 23 & 24 & 23 & 23 & 22 & 20 & 18 & 7 \\
\hline 15 & 1 & 24 & 7 & 18 & 27 & 4 & 37 & 2 & 15 & 27 & 26 & 23 & 22 & 2 & 21 & 23 & 18 & 8 \\
\hline
\end{tabular}

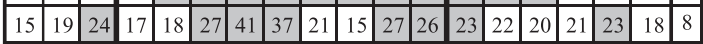
\begin{tabular}{|l|llllllllllllllllllllll}
14 & 17 & 23 & 26 & 23 & 24 & 20 & 33 & 21 & 18 & 29 & 23 & 23 & 22 & 21 & 22 & 20 & 17 & 9 \\
\hline 12 & 6 & 21 & 23 & 23 & 26 & 23 & 25 & 24 & 25 & 21 & 20 & 1 & 17 & 15 & 15 & 15 & 19 & 0 \\
\hline
\end{tabular}

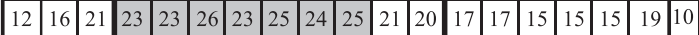
\begin{tabular}{|l|l|l|l|l|l|l|l|l|l|l|l|l|l|l|l|l|l|l|}
\hline 13 & 16 & 22 & 25 & 24 & 26 & 19 & 24 & 21 & 22 & 23 & 21 & 21 & 19 & 19 & 16 & 15 & 19 & 11 \\
\hline 10 & 6 & 22 & 22 & 24 & 27 & 14 & 14 & 2 & 20 & 1 & 13 & 2 & 22 & 2 & 21 & 4 & 18 & \\
\hline
\end{tabular} \begin{tabular}{llllllllll|l|l|l|l|l|l|l|l|l|l|l|}
\hline 10 & 16 & 22 & 22 & 24 & 27 & 14 & 14 & 25 & 20 & 14 & 13 & 23 & 22 & 22 & 21 & 14 & 18 & 12 \\
\hline 13 & 17 & 1 & 20 & 22 & 21 & 24 & 27 & 24 & 16 & 24 & 23 & 2 & 21 & 22 & & 14 & 16 & 13 \\
\hline
\end{tabular}

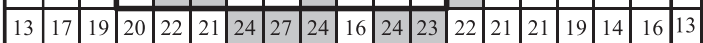
\begin{tabular}{l|lll|llllllllllllllllll|l|}
11 & 16 & 21 & 22 & 20 & 24 & 24 & 24 & 21 & 16 & 23 & 22 & 22 & 22 & 20 & 20 & 15 & 16 & 14 \\
\hline 11 & 14 & 20 & & 21 & 21 & & 21 & 24 & 14 & 22 & 21 & 22 & 22 & 20 & & 14 & 17 & 15 \\
\hline
\end{tabular} \begin{tabular}{lllllllllllllllllllllllll|}
\hline 11 & 14 & 20 & 19 & 21 & 21 & 19 & 21 & 24 & 14 & 22 & 21 & 21 & 22 & 20 & 19 & 14 & 17 & 15 \\
\hline 10 & 3 & 14 & 11 & 1 & 14 & 1 & 14 & 1 & 15 & 2 & 22 & 24 & 21 & 23 & 21 & 17 & 18 & \\
\hline
\end{tabular} \begin{tabular}{llllllllllllllllllllllllll}
10 & 13 & 14 & 11 & 12 & 14 & 14 & 14 & 11 & 15 & 21 & 22 & 24 & 21 & 23 & 21 & 17 & 18 & 16 \\
\hline 15 & 1 & 13 & 1 & 15 & 7 & 16 & 6 & 14 & 14 & 22 & 22 & 22 & 21 & 2 & 21 & 4 & 11 & 7 \\
\hline
\end{tabular}

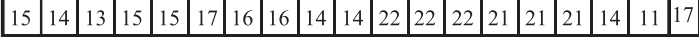

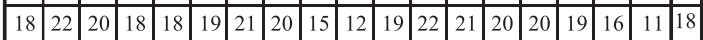

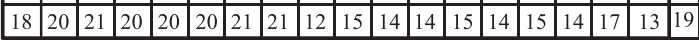

Detection limit value : $22 \mathrm{cps}$ count rate (cps)

\section{Points over detection limit valu}

Radioactive contamination area on the basis of the results of the calculation

Fig. 6 Count rates measured using a NaI scintillation survey meter of the floor.

Shield

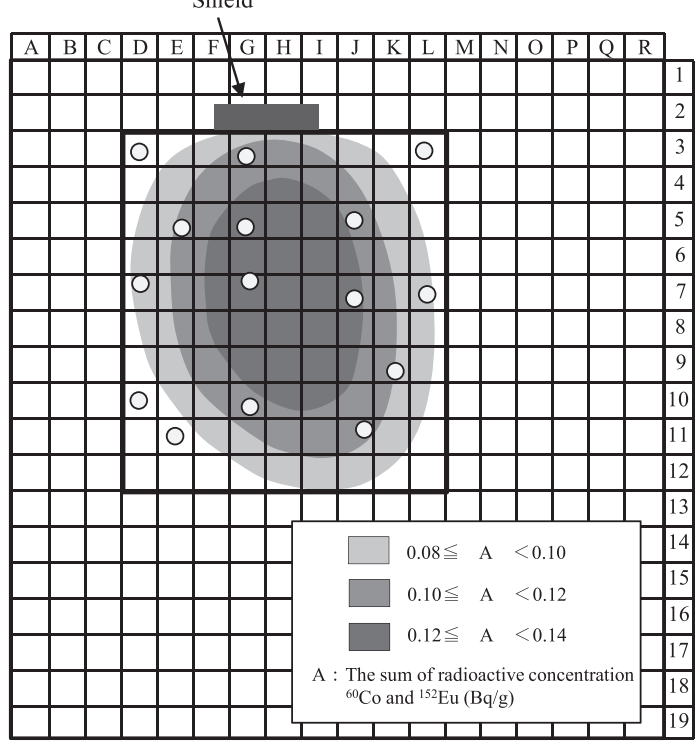

O Sampling points

Radioactive contamination area on the basis of the results of the calculation

Fig. 8 The development diagram and the sampling points of the floor using a high-purity germanium detector.

これらの測定結果は，計算結果を超えることはな く, 樑さ方向については深さ $30 \mathrm{~cm}$ を超えては検出限 界值未満であり放射化されていないと判断した。

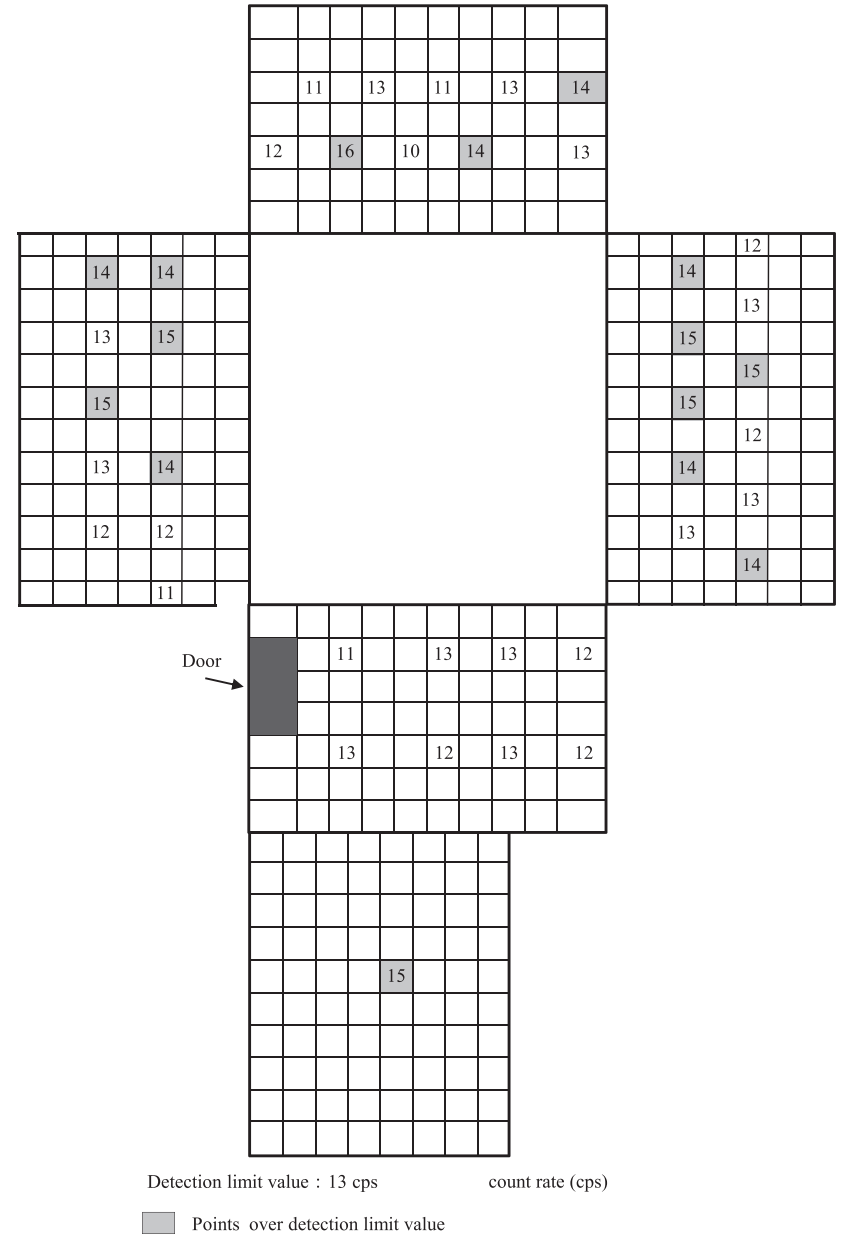

Fig. 7 Count rates measured result using a NaI scintillation survey meter on the walls and the ceiling.

\section{2-3＼cjkstart除染範囲の決定}

2-1にて決定した污染範囲である, 床面において本 体ターゲット直下をほぼ中心に縦 $3.0 \mathrm{~m} \times$ 横 $2.7 \mathrm{~m}$, 深 さ方向については $30 \mathrm{~cm}$ は, 2-2-1 および2-2-2 の結果 から計算による污染範囲が適正であると判断し，上記 の範囲を除染範囲とした(Fig. 9).

\section{2-4 放射化物の除去後の確認}

2-3で決定した除染範囲で放射化によるコンクリー トの污染物を除去した後の床面の測定結果を Fig. 10, 壁，天井面の測定結果を Fig. 11 に示す。測定結果は すべて検出限界值以下であった。

\section{3. 考 察}

放射性物質や放射線に関して国民の関心が高い現 在，放射化により污染された物質を安全に廃棄するこ とは重要である。

今回, 廃棄対象の非自己遮蔽型サイクロトロンおよ び周辺機器, サイクロトロン室のコンクリート等の廃 
Table 2 Radioactive concentration result using a high-purity germanium detector of the floor

\begin{tabular}{|c|c|c|c|c|}
\hline \multirow{2}{*}{ Location } & \multirow{2}{*}{ Depth } & \multicolumn{3}{|c|}{ Radioactive concentration (Bq/g) } \\
\hline & & ${ }^{60} \mathrm{Co}$ & ${ }^{152} \mathrm{Eu}$ & Total \\
\hline \multirow[t]{4}{*}{ D-3 } & $10 \mathrm{~cm}(7 \sim 13 \mathrm{~cm})$ & $1.40 \mathrm{E}-2$ & $2.92 \mathrm{E}-2$ & 4.32E-2 \\
\hline & $20 \mathrm{~cm}(17 \sim 23 \mathrm{~cm})$ & $7.18 \mathrm{E}-3$ & $2.48 \mathrm{E}-2$ & $3.20 \mathrm{E}-2$ \\
\hline & $30 \mathrm{~cm}(27 \sim 33 \mathrm{~cm})$ & LOD & LOD & LOD \\
\hline & $40 \mathrm{~cm}(37 \sim 43 \mathrm{~cm})$ & LOD & LOD & LOD \\
\hline \multirow[t]{4}{*}{ D-7 } & $10 \mathrm{~cm}(7 \sim 13 \mathrm{~cm})$ & $1.75 \mathrm{E}-2$ & $3.87 \mathrm{E}-2$ & $5.62 \mathrm{E}-2$ \\
\hline & $20 \mathrm{~cm}(17 \sim 23 \mathrm{~cm})$ & $1.23 \mathrm{E}-2$ & $1.98 \mathrm{E}-2$ & $3.21 \mathrm{E}-2$ \\
\hline & $30 \mathrm{~cm}(27 \sim 33 \mathrm{~cm})$ & $8.06 \mathrm{E}-3$ & $1.34 \mathrm{E}-2$ & $2.15 \mathrm{E}-2$ \\
\hline & $40 \mathrm{~cm}(37 \sim 43 \mathrm{~cm})$ & LOD & LOD & LOD \\
\hline \multirow[t]{4}{*}{ D-10 } & $10 \mathrm{~cm}(7 \sim 13 \mathrm{~cm})$ & $1.38 \mathrm{E}-2$ & $3.34 \mathrm{E}-2$ & 4.72E-2 \\
\hline & $20 \mathrm{~cm}(17 \sim 23 \mathrm{~cm})$ & LOD & $2.39 \mathrm{E}-2$ & 2.39E-2 \\
\hline & $30 \mathrm{~cm}(27 \sim 33 \mathrm{~cm})$ & LOD & LOD & LOD \\
\hline & $40 \mathrm{~cm}(37 \sim 43 \mathrm{~cm})$ & LOD & LOD & LOD \\
\hline \multirow[t]{4}{*}{ E-5 } & $10 \mathrm{~cm}(7 \sim 13 \mathrm{~cm})$ & $5.83 \mathrm{E}-2$ & $1.02 \mathrm{E}-1$ & $1.60 \mathrm{E}-1$ \\
\hline & $20 \mathrm{~cm}(17 \sim 23 \mathrm{~cm})$ & $2.05 \mathrm{E}-2$ & $3.10 \mathrm{E}-2$ & $5.15 \mathrm{E}-2$ \\
\hline & $30 \mathrm{~cm}(27 \sim 33 \mathrm{~cm})$ & $9.09 \mathrm{E}-3$ & $2.43 \mathrm{E}-2$ & $3.34 \mathrm{E}-2$ \\
\hline & $40 \mathrm{~cm}(37 \sim 43 \mathrm{~cm})$ & LOD & LOD & LOD \\
\hline \multirow[t]{4}{*}{ G-3 } & $10 \mathrm{~cm}(7 \sim 13 \mathrm{~cm})$ & $3.78 \mathrm{E}-2$ & $7.10 \mathrm{E}-2$ & $1.09 \mathrm{E}-1$ \\
\hline & $20 \mathrm{~cm}(17 \sim 23 \mathrm{~cm})$ & $2.03 \mathrm{E}-2$ & $2.65 \mathrm{E}-2$ & 4.68E-2 \\
\hline & $30 \mathrm{~cm}(27 \sim 33 \mathrm{~cm})$ & LOD & LOD & LOD \\
\hline & $40 \mathrm{~cm}(37 \sim 43 \mathrm{~cm})$ & LOD & LOD & LOD \\
\hline \multirow[t]{4}{*}{ G-5 } & $10 \mathrm{~cm}(7 \sim 13 \mathrm{~cm})$ & $5.39 \mathrm{E}-2$ & $8.16 \mathrm{E}-2$ & $1.36 \mathrm{E}-1$ \\
\hline & $20 \mathrm{~cm}(17 \sim 23 \mathrm{~cm})$ & $1.67 \mathrm{E}-2$ & $4.42 \mathrm{E}-2$ & $6.09 \mathrm{E}-2$ \\
\hline & $30 \mathrm{~cm}(27 \sim 33 \mathrm{~cm})$ & $9.76 \mathrm{E}-3$ & $1.93 \mathrm{E}-2$ & $2.91 \mathrm{E}-2$ \\
\hline & $40 \mathrm{~cm}(37 \sim 43 \mathrm{~cm})$ & LOD & LOD & LOD \\
\hline \multirow[t]{4}{*}{ G-7 } & $10 \mathrm{~cm}(7 \sim 13 \mathrm{~cm})$ & $6.01 \mathrm{E}-2$ & $1.00 \mathrm{E}-1$ & $1.60 \mathrm{E}-1$ \\
\hline & $20 \mathrm{~cm}(17 \sim 23 \mathrm{~cm})$ & $3.22 \mathrm{E}-2$ & $6.03 \mathrm{E}-2$ & $9.25 \mathrm{E}-2$ \\
\hline & $30 \mathrm{~cm}(27 \sim 33 \mathrm{~cm})$ & $1.09 \mathrm{E}-2$ & $1.71 \mathrm{E}-2$ & $2.80 \mathrm{E}-2$ \\
\hline & $40 \mathrm{~cm}(37 \sim 43 \mathrm{~cm})$ & LOD & LOD & LOD \\
\hline \multirow[t]{4}{*}{ G-10 } & $10 \mathrm{~cm}(7 \sim 13 \mathrm{~cm})$ & $5.83 \mathrm{E}-2$ & $1.02 \mathrm{E}-1$ & $1.60 \mathrm{E}-1$ \\
\hline & $20 \mathrm{~cm}(17 \sim 23 \mathrm{~cm})$ & $4.03 \mathrm{E}-2$ & $7.01 \mathrm{E}-2$ & $1.10 \mathrm{E}-1$ \\
\hline & $30 \mathrm{~cm}(27 \sim 33 \mathrm{~cm})$ & $1.90 \mathrm{E}-2$ & $2.95 \mathrm{E}-2$ & $4.85 \mathrm{E}-1$ \\
\hline & $40 \mathrm{~cm}(37 \sim 43 \mathrm{~cm})$ & LOD & $1.93 \mathrm{E}-2$ & $1.93 \mathrm{E}-2$ \\
\hline \multirow[t]{4}{*}{$\mathrm{J}-5$} & $10 \mathrm{~cm}(7 \sim 13 \mathrm{~cm})$ & $4.62 \mathrm{E}-2$ & $5.42 \mathrm{E}-2$ & $1.00 \mathrm{E}-1$ \\
\hline & $20 \mathrm{~cm}(17 \sim 23 \mathrm{~cm})$ & $1.74 \mathrm{E}-2$ & $2.19 \mathrm{E}-2$ & $3.93 \mathrm{E}-2$ \\
\hline & $30 \mathrm{~cm}(27 \sim 33 \mathrm{~cm})$ & $7.53 \mathrm{E}-3$ & LOD & $7.53 \mathrm{E}-3$ \\
\hline & $40 \mathrm{~cm}(37 \sim 43 \mathrm{~cm})$ & LOD & LOD & LOD \\
\hline \multirow[t]{4}{*}{$\mathrm{J}-7$} & $10 \mathrm{~cm}(7 \sim 13 \mathrm{~cm})$ & $4.97 \mathrm{E}-2$ & $8.06 \mathrm{E}-2$ & $1.30 \mathrm{E}-1$ \\
\hline & $20 \mathrm{~cm}(17 \sim 23 \mathrm{~cm})$ & $1.26 \mathrm{E}-2$ & $2.90 \mathrm{E}-2$ & 4.16E-2 \\
\hline & $30 \mathrm{~cm}(27 \sim 33 \mathrm{~cm})$ & LOD & LOD & LOD \\
\hline & $40 \mathrm{~cm}(37 \sim 43 \mathrm{~cm})$ & LOD & LOD & LOD \\
\hline \multirow[t]{4}{*}{ K-9 } & $10 \mathrm{~cm}(7 \sim 13 \mathrm{~cm})$ & $3.20 \mathrm{E}-2$ & $5.76 \mathrm{E}-2$ & $8.96 \mathrm{E}-2$ \\
\hline & $20 \mathrm{~cm}(17 \sim 23 \mathrm{~cm})$ & LOD & $1.42 \mathrm{E}-2$ & $1.42 \mathrm{E}-2$ \\
\hline & $30 \mathrm{~cm}(27 \sim 33 \mathrm{~cm})$ & LOD & LOD & LOD \\
\hline & $40 \mathrm{~cm}(37 \sim 43 \mathrm{~cm})$ & LOD & LOD & LOD \\
\hline \multirow[t]{4}{*}{ L-3 } & $10 \mathrm{~cm}(7 \sim 13 \mathrm{~cm})$ & $1.34 \mathrm{E}-2$ & $2.66 \mathrm{E}-2$ & 4.00E-2 \\
\hline & $20 \mathrm{~cm}(17 \sim 23 \mathrm{~cm})$ & $7.32 \mathrm{E}-3$ & $1.48 \mathrm{E}-2$ & $2.21 \mathrm{E}-2$ \\
\hline & $30 \mathrm{~cm}(27 \sim 33 \mathrm{~cm})$ & LOD & LOD & LOD \\
\hline & $40 \mathrm{~cm}(37 \sim 43 \mathrm{~cm})$ & LOD & LOD & LOD \\
\hline \multirow[t]{4}{*}{ L-7 } & $10 \mathrm{~cm}(7 \sim 13 \mathrm{~cm})$ & $1.32 \mathrm{E}-2$ & $2.84 \mathrm{E}-2$ & 4.16E-2 \\
\hline & $20 \mathrm{~cm}(17 \sim 23 \mathrm{~cm})$ & LOD & $7.78 \mathrm{E}-3$ & $7.78 \mathrm{E}-3$ \\
\hline & $30 \mathrm{~cm}(27 \sim 33 \mathrm{~cm})$ & LOD & LOD & LOD \\
\hline & $40 \mathrm{~cm}(37 \sim 43 \mathrm{~cm})$ & LOD & LOD & LOD \\
\hline E-11 & $10 \mathrm{~cm}(7 \sim 13 \mathrm{~cm})$ & $1.60 \mathrm{E}-2$ & $2.47 \mathrm{E}-2$ & 4.07E-2 \\
\hline & - & - & - & - \\
\hline & - & - & - & - \\
\hline & - & - & - & - \\
\hline $\mathrm{J}-11$ & $10 \mathrm{~cm}(7 \sim 13 \mathrm{~cm})$ & $3.20 \mathrm{E}-2$ & $8.04 \mathrm{E}-2$ & $1.12 \mathrm{E}-1$ \\
\hline & - & - & - & - \\
\hline & - & - & - & - \\
\hline & - & - & - & - \\
\hline
\end{tabular}

LOD: Limit of detection 

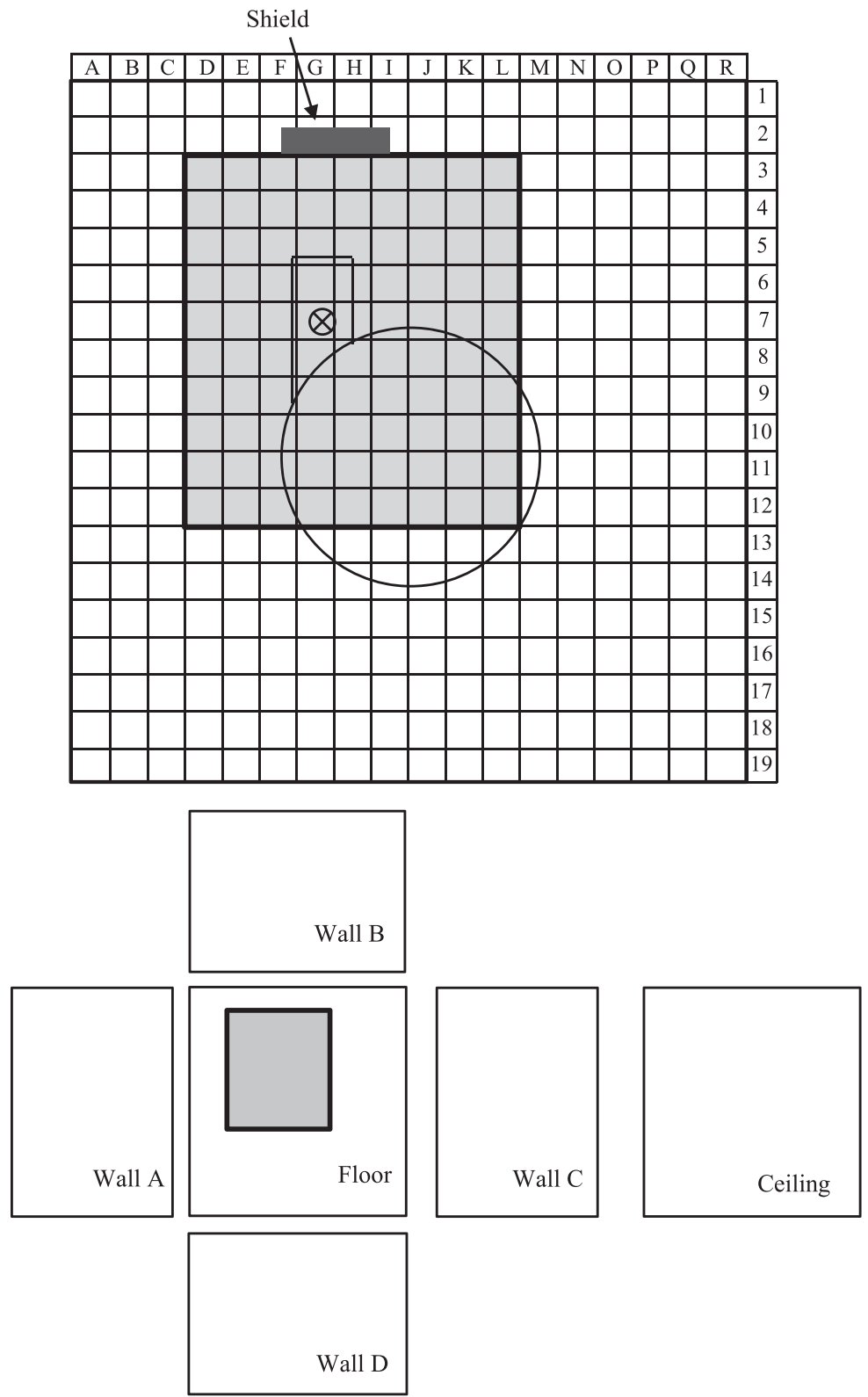

Decontamination area: $3.0 \mathrm{~m} \times 2.7 \mathrm{~m} \quad$ Depth : $30 \mathrm{~cm}$

Fig. 9 The development diagram of the decontamination area on the basis of the results of the calculation.

棄については障害防止法改正後，前例がないため，事 前に十分な検討を行い慎重に進めた。

最初に, サイクロトロン本体および周辺機器とサイ クロトロン室の 2 通りに分けて検討した。 サイクロト ロン本体および周辺機器は，障害防止法により，原則 として放射化物とするとある。ただし，信頼できる実 測デー夕，計算結果等により放射化物として取り扱う 必要がないことが確認できたものについては放射化物 としないことができるとあるため，污染範囲を同定す ることも考えたが，当施設では困難であると判断し， すべて放射性廃棄物として廃棄した ${ }^{11}$ 。

サイクロトロン室については，すべてのコンクリー
卜を放射性廃棄物として廃棄するには, 膨大な量の放 射性廃棄物となるため, 放射化により污染された部分 だけを放射性廃萧物として廃棄することとした。その ため, 污染の範囲を確認し, 安全側に除去する必要が ある。

污染範囲については, 計算により放射能濃度を算出 して放射化の範囲を決定し，その結果の妥当性を， サーベイメータによる計数率の測定および HP-Ge 半 導体検出器による放射能濃度の測定で確認した。測定 結果により，計算結果が安全側に評価されていること を確認した。これらの結果をもとに除染範囲を決定 し, 放射性廃棄物として廃棄した。除染後に, 再度 


\begin{tabular}{|c|c|c|c|c|c|c|c|c|c|c|c|c|c|c|c|c|c|c|}
\hline $\mathrm{A}$ & $\mathrm{B}$ & $\mathrm{C}$ & $\mathrm{D}$ & $\mathrm{E}$ & $\mathrm{F}$ & $\mathrm{G}$ & $\mathrm{H}$ & $\mathrm{I}$ & $\mathrm{J}$ & $\mathrm{K}$ & $\mathrm{L}$ & $\mathrm{M}$ & $\mathrm{N}$ & $\mathrm{O}$ & $\mathrm{P}$ & $\mathrm{Q}$ & $\mathrm{R}$ \\
\hline 9 & 11 & 10 & 10 & 10 & 10 & 10 & 11 & 10 & 11 & 11 & 10 & 7 & 7 & 6 & 6 & 5 & 9 & 1 \\
\hline 9 & 10 & 10 & 10 & 11 & 11 & 11 & 11 & 11 & 12 & 12 & 10 & 6 & 6 & 5 & 6 & 5 & 10 & 2 \\
\hline 9 & 11 & 11 & 9 & 9 & 9 & 9 & 9 & 9 & 9 & 9 & 9 & 6 & 5 & 5 & 5 & 5 & 8 & 3 \\
\hline 10 & 10 & 9 & 9 & 9 & 9 & 10 & 9 & 8 & 8 & 9 & 9 & 5 & 6 & 6 & 6 & 5 & 9 & 4 \\
\hline 10 & 10 & 11 & 9 & 9 & 9 & 9 & 10 & 9 & 10 & 9 & 9 & 11 & 10 & 8 & 8 & 11 & 10 & 5 \\
\hline 9 & 9 & 10 & 8 & 8 & 9 & 9 & 8 & 8 & 9 & 9 & 8 & 10 & 9 & 10 & 10 & 10 & 9 & 6 \\
\hline 10 & 11 & 10 & 8 & 9 & 9 & 8 & 10 & 9 & 9 & 9 & 9 & 11 & 10 & 10 & 9 & 10 & 9 & 7 \\
\hline 10 & 10 & 10 & 9 & 8 & 9 & 9 & 9 & 9 & 8 & 9 & 8 & 11 & 10 & 10 & 9 & 10 & 9 & 8 \\
\hline 10 & 10 & 10 & 9 & 9 & 9 & 10 & 9 & 10 & 9 & 9 & 9 & 10 & 11 & 11 & 11 & 10 & 9 & 9 \\
\hline 9 & 11 & 11 & 8 & 8 & 8 & 9 & 10 & 9 & 9 & 9 & 9 & 10 & 10 & 10 & 9 & 9 & 10 & 10 \\
\hline 9 & 11 & 11 & 9 & 9 & 9 & 8 & 9 & 8 & 9 & 9 & 9 & 10 & 10 & 9 & 9 & 9 & 9 & 11 \\
\hline 9 & 9 & 10 & 9 & 9 & 9 & 9 & 8 & 9 & 8 & 9 & 9 & 11 & 10 & 10 & 9 & 9 & 10 & 12 \\
\hline 9 & 9 & 9 & 10 & 11 & 12 & 12 & 12 & 12 & 12 & 11 & 11 & 10 & 10 & 10 & 10 & 9 & 10 & 13 \\
\hline 9 & 9 & 11 & 11 & 10 & 11 & 10 & 12 & 11 & 12 & 10 & 11 & 10 & 10 & 10 & 9 & 9 & 10 & 14 \\
\hline 8 & 11 & 10 & 9 & 10 & 11 & 10 & 9 & 10 & 11 & 11 & 11 & 10 & 10 & 9 & 10 & 8 & 9 & 15 \\
\hline 10 & 8 & 9 & 9 & 9 & 10 & 9 & 9 & 9 & 10 & 10 & 10 & 10 & 11 & 10 & 9 & 9 & 10 & 16 \\
\hline 10 & 11 & 10 & 10 & 9 & 10 & 10 & 10 & 9 & 10 & 10 & 11 & 10 & 10 & 9 & 8 & 9 & 9 & 17 \\
\hline 10 & 9 & 9 & 10 & 11 & 10 & 10 & 11 & 9 & 9 & 11 & 11 & 11 & 10 & 9 & 9 & 8 & 8 & 18 \\
\hline 9 & 9 & 9 & 9 & 10 & 10 & 9 & 10 & 11 & 8 & 8 & 10 & 9 & 10 & 10 & 10 & 9 & 9 & 19 \\
\hline
\end{tabular}

Detection limit value : $12 \mathrm{cps}$

count rate (cps)

The area after decontamination

Fig. 10 Count rates measured using a $\mathrm{NaI}$ scintillation survey meter of the floor after decontamination.

サーベイメータで測定し, すべての場所で検出限界值 以下であることを確認した。污染範囲は適切に除染で きた。

計算による放射能濃度分布の評価方法は, サイクロ トロンの運転履歴，過去の文献，コンクリートのコア 抜きのデー夕を参考に中性子の発生量を推定し, 放射 化による放射能濃度の分布を作成した。

中性子量の発生については, サイクロトロンが既に 停止していたため中性子発生量を推定したが, 停止前

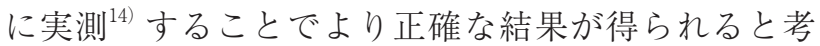
える。また，モンテカルロ等による計算評価 ${ }^{8,11}$ も行 われているが, 今回は基本的な計算式 ${ }^{15)}$ を用い, 必要 な数值を文献等から参照し算出した。これらの計算手 法を検証するために，コンクリートのコア抜きによる 放射能濃度の測定結果が有効であった。モンテカルロ 等の方法では, 連続的な結果が得られるが, 今回の方 法で連続的な結果を得るためには評価点を多くする必 要があり，結果，作業が煩雑になるのも事実である。

次に, サーベイメータで床, 壁, 天井面を直接測定 した結果, 放射化による生成対象核種のうちの ${ }^{60} \mathrm{Co} の$ $\Upsilon$ 線エネルギーは高いため測定エリア外の放射線の影 響を受けたが，計算による結果とほぼ同様の傾向がみ られた。

サーベイメータによる測定では，除染前は，放射化

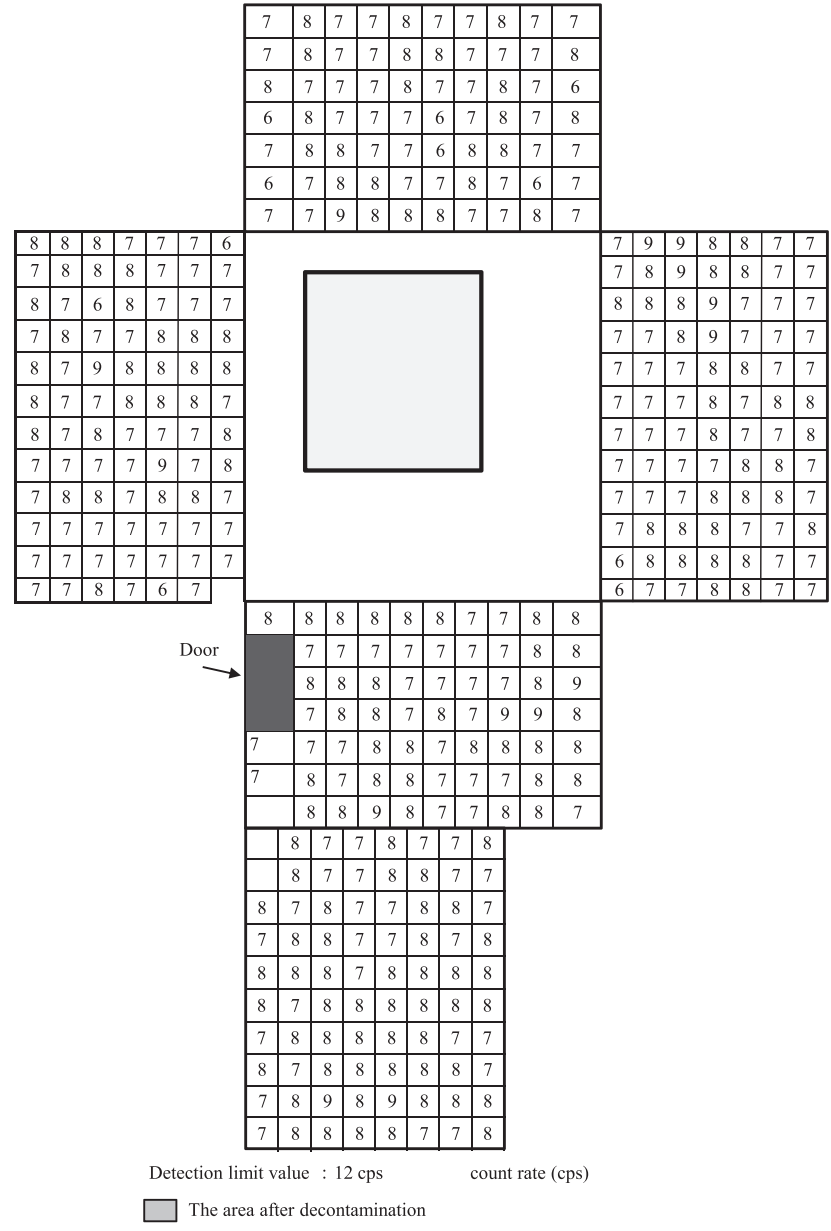

Fig. 11 Count rates measured using a NaI scintillation survey meter of the walls and the ceiling after decontamination.

の可能性の低い壁，天井面で検出限界を超える箇所が あり，これは周囲からの放射線の影響が測定值を過大 評価させると考えた。しかし，周囲のからの放射線を 完全に遮蔽して測定することは不可能であるため, 今 回は，後述のコア抜き箇所の決定等の参考とした。

更に，計算で高值を示した 15 カ所からコンクリー トを採取し HP-Ge 半導体検出器で測定した。これら の測定結果より，計算による評価が安全側であったと 判断できた。また， $30 \mathrm{~cm}$ より深くなると検出限界值 以下であることが確認された. HP-Ge 半導体検出器 を用いることで深さ方向の污染評価が可能であった。

コンクリートをコア抜きして HP-Ge 半導体検出器 で測定する方法は，正確に放射能濃度を評価できる が、コア抜きした部分のみの評価にとどまり，詳細な 放射能濃度分布を作成するためには，サンプル数を増 やす必要がある。作業時間等を考慮すると実際的では ない。そこで，今回は計算結果を確認できる最小限の 箇所の測定にとどめた。

除染後の評価は, サーベイメータによる方法で実施 
したが，すべて検出限界值以下であることが確認できた。 放射性廃棄物をできる限り減らすためにも，正確な 計算による評価が有効である。更に，サーベイメータ や HP-Ge 半導体検出器で測定することで計算結果が より安全側に立った評価であることを確認することが 重要である。

最後に, 今後もサイクロトロン本体およびその設置 施設を廃止する施設は増加すると考えられる。廃止決 定前に十分な事前準備を行うことが重要であり，施設 ごとに最適な評価は必要となるが，今回の放射化によ る污染の評価には中性子発生量の把握が重要となり, サイクロトロンが稼働中に実測することができるもの である，当施設では，運転停止していたため実測でき なかった。そのため，この中性子発生量は文献等をも とに推定し決定した。この作業では推定の域を超えな いことも事実である。放射線治療装置においては，関 連学会の検討により放射化物の管理に関する学会標 準 $^{16)}$ が出されている。 サイクロトロンにおいても同 じように，その方法など情報共有できる環境が整うこ
とを望み，当施設での経験が活かせるよう協力するこ とを惜しまない.

\section{4. 結 語}

今回, 非自己遮蔽型サイクロトロンおよび周辺機 器, サイクロトロン室の廃棄にあたり, 本体および周 辺機器はすべて放射性廃棄物として処理した。また, サイクロトロン室のコンクリートに関しては, 計算に よる評価にて污染範囲を決定し, サーベイメータ等に よる実測によりその妥当性を検証した後に除去した。 更に，除去後にサーベイメータによる測定を実施し， すべて検出限界以下であることを確認し, 適切に除染 できた。

\section{謝 辞}

今回のサイクロトロンの廃棄にあたり当院の医療管 理係の方々にご協力，ご支援をしていただきました。 皆様に心より感謝いたします。

\section{参考文献}

1）公益社団法人日本アイソトープ協会. 放射線利用統計 2012. http://www.jrias.or.jp/e/pdf/the use_of radiation 2012.pdf (cited 2015 April 9).

2）文部科学省科学技術 - 学術政策局 原子力安全課放射線規 制室．放射性同位元素等による放射線障害の防止に関す る法律の一部を改正する法律並びに関係政令, 省令及び 告示の施行について. 平成 24 年 3 月.

3) 堀次元気, 渡邊 浩, 藤淵俊王, 他. PET 核種製造用サイ クロトロン利用に伴う放射化物の管理について。 日放技 学誌 2014; 70(3): 287-297.

4) Fujibuchi $T$, Nohtomi A, Baba $S$, et al. Distribution of residual long-lived radioactivity in the inner concrete walls of a compact medical cyclotron vault room. Ann Nucl Med 2015; 29(1): 8490.

5）緒方良至, 石榑信人, 望月真吾, 他. PET サイクロトロン 設置室内外の中性子束. 日本放射線安全管理学会誌 2008; 7(1): 35-40.

6) Fujibuchi T, Yamaguchi I, Kasahara T, et al. Measurement of thermal neutron fluence distribution with use of $23 \mathrm{Na}$ radioactivation around a medical compact cyclotron. Radiol Phys Technol 2009; 2(2): 159-165.

7) $\mathrm{F}$ Fernandez, $\mathrm{K}$ Amgarou, $\mathrm{C}$ Domingo, et al. Neutron Spectrometry in a PET Cyclotron with a Bonner Sphere System. Radiat Prot Dosimetry 2007; 126(1-4): 371-375.

8) Méndez R, Iñiguez MP, Martí-Climent JM, et al. Study of the neutron field in the vicinity of an unshielded PET cyclotron.
Phys Med Biol 2005; 50(21): 5141-5152.

9）公益財団法人原子力安全技術センター。構造材元素組成 デー夕 (Table 12, Table 13). https://www.nustec.or.jp/an zenjissho/introduction/gal_4.html\#t12 (cited 2015 April 9).

10）公益財団法人日本アイソトープ協会. 天然同位体存在度 および熱中性子断面積.アイソトープ手帳 第 11 版. 丸 善出版, 東京, 2011: 112-123.

11) Martínez-Serrano JJ, Díez de los Ríos A. Prediction of neutron induced radioactivity in the concrete walls of a PET cyclotron vault room with MCNPX. Med Phys 2010; 37(11): 6015-6021.

12) Yamaguchi I, Kasahara K, Fujibuchi $T$, et al. Radiation safety management of residual long-lived radioactivity distributed in an inner concrete wall of a medical cyclotron room. Radiation Protection Dosimetry 2011; 146(1-3): 167-169.

13）木村健一, 石川敏夫, 山寺 亮, 他. サイクロトロン建屋 コンクリートの放射化測定. Radioisotopes 1992; 41: 213217.

14) Ogata $Y$, Ishigure $N$, Mochizuki $S$, et al. Distribution of thermal neutron flux around a PET cyclotron. Health Phys 2011; 100 Suppl 2: S60-66.

15）公益財団法人日本アイソトープ協会. 主要公式集.アイ ソトープ手帳 第 11 版. 丸善出版, 東京, 2011: 4-5.

16）阿部容久, 大山正哉, 藤淵俊王, 他. 放射線治療装置にお ける放射化物の管理に関する学会標準 初版 (平成 26 年 4 月 14 日). http://www.jart.jp/news/tclj8k0000000we0-att/li nac_standerd_260414.pdf (cited 2015 October 9). 